\title{
Building visions and expectations in language teacher education: A study of Hungarian and Turkish pre-service EFL teachers
}

\author{
Kornél Farkas \\ Institute of English Studies, Department of English Applied Linguistics, Pécs, Hungary \\ farkas.kornel@pte.hu
}

\section{Introduction}

As a contribution to a growing body of research on the theory and practice of reflective teaching in language teacher education, this study examines the results of a structured reflective activity in which Hungarian $(n=30)$ and Turkish $(n=17)$ pre-service EFL teachers were asked to express not only beliefs and knowledge derived from their past experiences (Borg, 2003, 2006), but also their visions and expectations regarding their future selves in the profession (Dörnyei \& Kubanyiova, 2014). The recognition that teaching-related visions and expectations should also be addressed in teacher education programmes has only gained momentum in recent years, inspired by major developments in motivation research (Section 2.2) and by some pioneering studies conducted in Finland (e.g., Kalaja, 2015; Kalaja \& Mäntylä, 2018).

In addition to these origins, further reasons for the exploration of teaching-related visions and expectations were put forward by Lampert, Burnett, and Davie (2012), who suggested that the mismatches between pre-service EFL teachers' expectations and job realities are one of the main causes for early teacher attrition and burnout in this profession, and by Peacock (2001), who demonstrated the tendency of pre-service EFL teachers to hold beliefs that are inhibitory to teacher motivation and professional growth (see also Moore, 2004). Whereas these claims are also supported by the results of this study, the exploration of teaching-related visions and expectations will be presented as an activity through which pre-service EFL teachers' existing knowledge and dispositions can be externalised and potentially reconceptualised as part of their professional coursework (Johnson, 2009, 2015) in local or even cross-cultural communities of practice (Kumaravadivelu, 2012).

\section{Theoretical background}

\subsection{The role of reflection in language teacher education}

Although in past decades the education of English teachers has been shaped and characterised by a variety of research-based, multi-disciplinary innovations (see Hyland \& 
Wong, 2013), the most substantial of these has been, arguably, the adoption of reflective teaching as a standard model in the teaching of English as a foreign or second language (TEFL/TESOL). This strong commitment to the theory and practice of reflective teaching has grown out of the quickly advancing study of language teacher cognition starting in the 1980s, whereby some teacher researchers started to explore the thinking, sense-making, and learning processes of language teachers, and found that engagement in reflective activities made the teachers more attentive to the critical examination and reconceptualization of their knowledge, dispositions, and classroom experiences (McDiarmid \& Clevenger-Bright, 2008, p. 139).

A major outcome from this line of research has recently been the conceptualisation of language teacher cognition as a highly complex, practically oriented, personalized, and context-sensitive network of knowledge, thoughts and beliefs (Borg, 2006, p. 272), which develops continuously via the teaching-related activities (Feryok, 2012) that teachers go through as language learners, as learners of teaching, and as classroom practitioners (Borg, 2003, p. 82). Considering that teachers' classroom practices are necessarily (and often implicitly) influenced by the notions and dispositions derived from past experience (Kumaravadivelu, 2012, p. 60), it is also important to emphasize that the reflective activities in which language teachers are engaged have the potential to transform their earlier cognitions (Bartlett, 1990), and thus facilitate teachers' conceptual growth, their understanding of their own classroom practice, and, in essence, their learning (Johnson, 2009). In an explanation similar to this, Korthagen (2011, pp. 36-37) states the following:

"When a teacher reflects, often a previously unconscious gestalt develops into a conscious network of concepts, characteristics, principles, and so on, which is helpful in describing practice."

While this view implies that in the classroom practice of a typical language teacher a number of behaviours (depending on the teacher's expertise) tend to be grounded in unanalysed chunks of "earlier experiences, role models, needs, values, feelings, images and routines" (Korthagen, 2004, p. 81), Korthagen's (2011) research also suggests that even the most elusive components of language teacher cognition (e.g., gestalts) can become transparent through reflective activity. As these claims have been consistently supported by research on language teachers' reflective activity (e.g., Borg, 2006; Johnson, 2009; Kubanyiova \& Feryok, 2015), it is easy to see why reflective teaching has become a standard model in TEFL/TESOL, urging teacher educators around the globe to realise that "making tacit knowledge explicit by reflection is a necessary step in order for fundamental change to occur in teacher behaviour" (Lugossy, 2006, p. 339), and that for teachers to become 'reflective practitioners,' they need to acquire both "the skill and attitude of making one's own actions, feelings, experiences the objects of one's thinking" (Kelchtermans, 2009, p. 267).

Moving further along the same thread, research on reflective teaching has also drawn attention lately to teacher educators' role as mediators and facilitators of language teachers' reflective activity, ideally engaging teachers in ongoing dialogic interaction (Chick, 2015) and ensuring that both the focus and type of reflective activity are in tune with the teachers' 
current stage of professional development (Johnson, 2015). In the sections that follow, ideas about the focus of language teachers' reflective activity are examined in light of novel approaches to language teacher motivation (Dörnyei \& Kubanyiova, 2014) as well as visions and future self-guides of pre-service EFL teachers (e.g., Kalaja, 2015; Kalaja \& Mäntylä, 2018).

\subsection{Expanding the scope of language teachers' reflective activity: The case of visions and expectations}

The developments described in this section are primarily related to the focus of the reflective activity in which language teachers may be engaged as part of their professional coursework. While in the previous section it was pointed out that theories and practices of reflective teaching are already seen as an integral part of language teacher education programmes around the world, a closer look at the studies cited there (e.g., Borg, 2003; Johnson, 2015; Korthagen, 2011; Lugossy, 2006) reveals that much of language teachers' reflective activity has traditionally focused on how past experience shapes teachers' sense-making and dispositions. Recently, however, a new line of research has reminded researchers and teacher educators that language teachers' cognitions are simultaneously shaped by "meaningful experiences in the past and expectations about the future" (Kelchtermans, 2009, p. 263), thus implying that exploring and shaping teachers' visions and expectations (Dörnyei \& Kubanyiova, 2014; Kalaja, 2015) is an equally important task for teacher research and education.

To understand the role of this type of conceptual work in language teachers' development, it is indispensable to look at Dörnyei's (2009) highly appraised model of language learning motivation, more specifically, at the notion of possible selves (a key component in the model). The term, which is increasingly used in describing the dynamics of language teacher motivation as well (e.g., Dörnyei \& Kubanyiova, 2014; Kubanyiova, 2009), has been recently defined by Dörnyei and Ryan (2015) as follows:

"Possible selves are specific representations of one's self in future states, involving thoughts, images, and senses, and are in many ways the manifestations, or personalized carriers, of one's goals and aspirations (or fears, of course). This being the case, possible selves incite and direct purposeful behaviour, and the more vivid and elaborate the selfimage is, the more motivationally effective it is expected to be." (p. 87)

Implicit in this definition, as argued in Dörnyei and Kubanyiova (2014), is an emphatic statement about the value of reflective activities through which pre-service EFL teachers have a chance to understand the role of possible selves in one's professional development, and to experience the process by which existing visions and expectations may be transformed into realistic but positively loaded future self-guides (see also Kelchtermans, 2009; Korthagen, 2004, 2011). This process of construing and constructing positive future self-guides is, according to Dörnyei and Ryan (2015, p. 96), one of the highest-order motivational forces in individuals. Similarly to other types of reflective activity, however, conceptual work with visions and expectations is also considered the most effective if 
supervised by teacher educators as expert mediators (Dörnyei \& Chan, 2013; Dörnyei \& Kubanyiova, 2014) - a process which I aim to demonstrate in the empirical sections of this study.

\section{The study}

\subsection{Aim and research question}

As part of a multi-stranded enquiry into the teaching-related beliefs and reflections of preservice EFL teachers, the current study was conducted to look into the visions, expectations, and future self-guides characterising three groups of participants in two different educational contexts. Considering that the amount of research into teaching-related visions and expectations has been fairly limited so far, the qualitative orientation of the study was expected to bring about a varied and in-depth exploration of these concepts, and thereby an answer to the following research question:

What are the teaching-related visions and expectations that best characterise the Hungarian and Turkish pre-service EFL teachers participating in this study, and what are the implications of these for language teacher education?

\subsection{Data collection instrument}

The qualitative data for this study were collected in the form of short, written beliefstatements through a self-designed instrument for language teacher reflection, which I elsewhere called a reflective template (Farkas, 2019). Essentially, the reflective template (Appendix A) is a selection of ten sentence-starters that elicit language teachers' teachingrelated beliefs and experiences in a feasible form, with some items tapping specifically into teachers' visions and expectations about the teaching profession and their future professional selves. In order to maintain a clear focus on the latter components, the analysis in this study only involves the participants' responses to Statement 2 (If I was working as a teacher, the most important thing I would teach my students is...) and to Statement 7 (The job of a language teacher is harder/easier, because...); the latter allowed for a choice between two alternatives. Whereas the responses to Statement 2 were considered representative of pre-service EFL teachers' visions and future self-guides, Statement 7 was selected due to its focus on the participants' expectations regarding the difficulty of language teaching in relation to teaching other subjects.

\subsection{Participants}

As mentioned earlier, the participants of the study were Hungarian ( $n=12+18$; two groups) and Turkish ( $\mathrm{n}=17$ ) pre-service EFL teachers, who filled in the reflective template (Appendix 
A) as part of their professional coursework at their home universities, and agreed to their responses being used anonymously as research data. More specifically, the data were collected in three consecutive stages: first from a group of 12 Hungarian pre-service EFL teachers in 2015; then from a group of 17 Turkish pre-service EFL teachers in 2016-in collaboration with Dombaycı (2016), who analysed the same dataset on a separate project; and finally from another group of 18 Hungarian pre-service EFL teachers. The age of the participants ranged between 20 to 24 years, and each group consisted of both male and female participants (though gender distribution was not specifically observed and quantified).

At the time of data collection, each group was going through the introductory phase of teacher education prior to the teaching practicum, which, under current policy, is introduced in the fourth year of studies in Hungary (Kontra, 2016), and in the third year of studies in Turkey (Toköz Göktepe, 2015). Thus, when formulating their belief-statements for the study, the participants were drawing on their knowledge and dispositions derived from their experiences as language learners and from their professional coursework, rather than from first-hand experience of teaching language classes. For more information on the educational contexts and the teacher educational models of the countries involved, readers are advised to consult Kontra (2016) and Medgyes (2015) about EFL teaching and teacher education in Hungary, and Toköz Göktepe (2015) about EFL teaching and teacher education in Turkey.

\subsection{Data collection and analysis}

Although the data for this study were collected in three consecutive stages (see above), the participants' responses were analysed through the same procedure in each group. After collecting pre-service teachers' belief-statements in paper-and-pencil format, the data of each group were entered into a separate electronic data file, in which the statements were gathered under the ten sentence-starters presented in Appendix A. Then, in a process of qualitative content analysis similar to Barkhuizen and Wette's (2008), the belief-statements were further categorised along the themes and patterns emerging from the data. Subsequent to this, comparisons within and across the three groups and interpretations of the results were made, thus revealing salient themes related to the participants' teaching-related expectations and future self-guides.

Despite working with a relatively small dataset, I marked the salience of emerging themes by indicating their frequency of occurrence within the three observed groups, and by including illustrative quotes for each theme in the upcoming sections. To identify the authors of the quotes, each participant was given a personal identification number: HA\#11, for instance, is a participant from the first Hungarian group ( $n=12)$, HB\#11 is a participant from the second Hungarian group ( $\mathrm{n}=18)$, and TA\#11 is a participant from the Turkish group $(\mathrm{n}=17)$ respectively. 


\section{Results and discussion}

\subsection{Pre-service EFL teachers' visions of their future professional selves}

To start with a structured overlook of the teaching-related visions and future self-guides that characterised the three groups, Table 1 below shows the themes and categories that emerged from the participants' responses to Statement 2 in the reflective template (see Section 3.2).

Table 1. Emerging themes regarding visions of future teaching (numbers indicate how frequently a specific theme occurred in the three groups)

\section{Statement \#2: If I was working as a teacher, the most important thing I would teach my students is...}

\begin{tabular}{|c|c|c|}
\hline 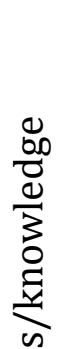 & $\begin{array}{l}\text { Theme } 1.1 \\
\text { (setting personal } \\
\text { goals) } \\
\text { TA(n=6) } \\
H A(n=2) \\
H B(n=2)\end{array}$ & $\begin{array}{l}\text { - following their dreams and finding the thing that makes } \\
\text { them happy. (TA\#9) } \\
\text { - how to learn, how to improve by themselves, and how to } \\
\text { find their real interests. (HA\#12) } \\
\text { - to find a long-term goal and go for it. (HB\#1) }\end{array}$ \\
\hline 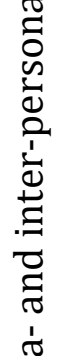 & $\begin{array}{l}\text { Theme } 1.2 \\
\text { (increasing self- } \\
\text { efficacy) } \\
\operatorname{TA}(\mathrm{n}=8) \\
\mathrm{HA}(\mathrm{n}=2) \\
\mathrm{HB}(\mathrm{n}=3)\end{array}$ & $\begin{array}{l}\text { - being honest and hard-working. (TA\#13) } \\
\text { - to be confident and hard-working, because with these } \\
\text { two they can achieve anything. (HA\#8) } \\
\text { - that they believe in themselves. There is nothing they } \\
\text { cannot do. (TA\#8) }\end{array}$ \\
\hline 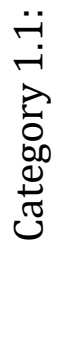 & $\begin{array}{l}\text { Theme } 1.3 \\
\text { (respecting others' } \\
\text { lives and ideas) } \\
\operatorname{TA}(\mathrm{n}=3) \\
\mathrm{HA}(\mathrm{n}=2) \\
\mathrm{HB}(\mathrm{n}=2)\end{array}$ & $\begin{array}{l}\text { - to be good [respectful] to each other. (HA\#5) } \\
\text { - respecting other people's lives and ideas. (TA\#6) } \\
\text { - how to work in pairs and teams. (HB\#2) } \\
\text { - communication, integrity, respect for others, } \\
\text { independence. (HB\#13) }\end{array}$ \\
\hline
\end{tabular}




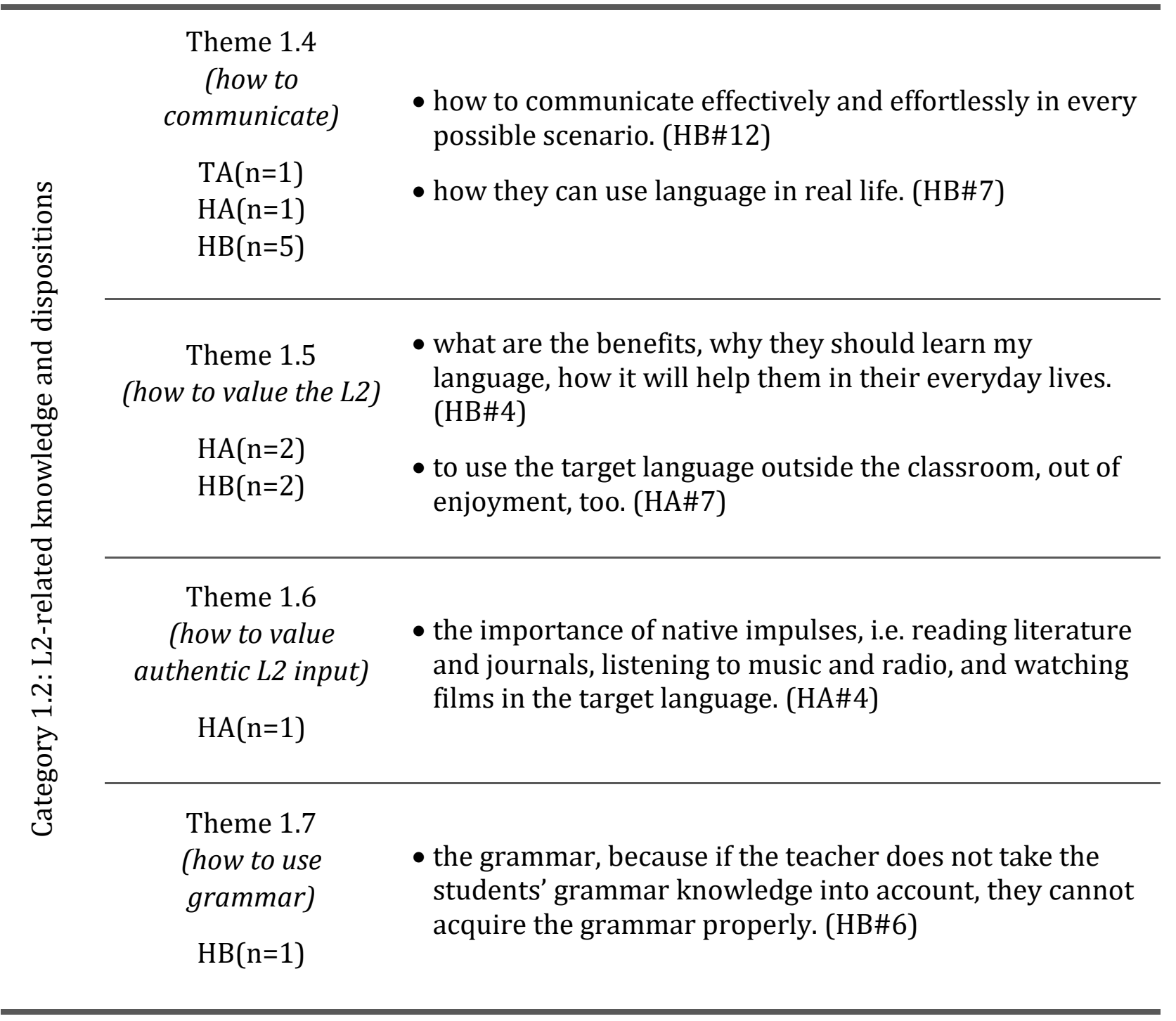

Together with the themes and the illustrative quotes, the two main categories in Table 1 reflect a clear division between two types of future self-guides: one in which EFL teachers' focus is on developing students' L2-related knowledge and dispositions (Category 1.2), and one in which the focus is on what I should call the intra- and interpersonal skills and knowledge of the learner (Category 1.1). In fact, the frequency data in Table 1 indicate an obvious inclination to the latter category, suggesting that the majority of the participants (especially in the Turkish group) envisioned themselves not merely as language teachers, but rather as teachers whose main responsibility is to raise motivated, self-reflective, and autonomous learners, for whom the foreign language is only a tool to achieve success in other fields of life (Breen, 1999).

These findings, in turn, correspond with a recently observed re-appraisal of learnercentred and humanistic pedagogies among pre-service EFL teachers (e.g., Borg, Birello, Civera, \& Zanatta, 2014; Clarke, 2008; Kalaja, 2015), and indicate a growing concern for nurturing socio-emotional abilities in individual students as members of socio-culturally 
diverse learner groups (Warren, 2018). These abilities include both intrapersonal skills such as self-reflection, goal setting, and construing positive self-appraisals (Themes $1.1 \& 1.2$ ), and interpersonal skills such as cooperating with others in socially responsive ways (Theme 1.3). Clearly, as Kelchtermans (2009) and Korthagen (2004) argue, this emphatic concern for the socio-emotional abilities, the moral values, and the personal growth of learners should be accepted as a natural part of language teachers' task-perception and sense of responsibility. According to Dörnyei and Kubanyiova (2014), however, if a language teacher's envisioned professional self is too complex to be realistically attained, the vision might be inhibitory rather than conducive to professional development.

From this perspective, the themes enlisted in Category 1.2 might be viewed as evidence for the tendency of some participants to construe professional self-guides that are more easily attainable and more in tune with those competences that are generally in the focus of language teacher education (Borg \& Edmett, 2018). This is not meant to suggest that the visions captured in Category 1.1 should be devalued or rectified by teacher educators, but to call for reflective activities in which pre-service EFL teachers are not only required to express their current visions and understandings but also exposed to alternative and less complex professional self-guides, which they might build into their personal repertoire. By promoting such dialogue in local or cross-cultural communities of practice (Chick, 2015; Kumaravadivelu, 2012), teacher educators can trigger a process of conceptual change in which complex teaching-related visions (e.g., Category 1.1) are complemented with teaching goals that may be easier to attain in TEFL/TESOL (e.g., Category 1.2). Additionally, this type of knowledge construction plays an especially important role in the professional development of pre-service EFL teachers (Johnson, 2015), as their understandings, teaching practices, and motivations are known to change substantially as they gain first-hand experience of school life and teaching (e.g., Lampert et al., 2012; Yuan \& Lee, 2014).

\subsection{Pre-service EFL teachers' expectations about the difficulty of language teaching}

Turning away from the discussion of teaching-related visions and future self-guides, this section addresses another key component of pre-service EFL teachers' cognition: their expectations about the difficulty of language teaching in relation to teaching other subjects. Following a summary of the participants' responses to Statement 7 in the reflective template (see Table 2 below), the emerging themes and the underlying concepts are examined in more detail. 
Table 2. Emerging themes regarding the perceived difficulty of language teaching (numbers indicate how frequently a specific theme occurred in the three groups)

\begin{tabular}{|c|c|c|}
\hline \multirow{4}{*}{ 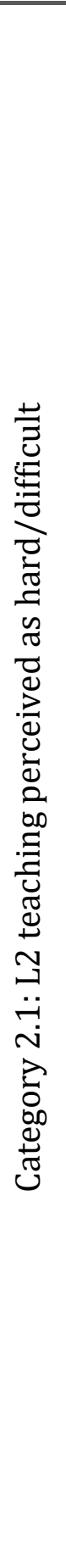 } & $\begin{array}{l}\text { Theme } 2.1 \\
\text { (L2 learning } \\
\text { as complex } \\
\text { mental } \\
\text { activity) } \\
\text { TA(n=4) } \\
\mathrm{HA}(\mathrm{n}=4) \\
\mathrm{HB}(\mathrm{n}=5)\end{array}$ & $\begin{array}{l}\text { - harder because what he or she teaches is in a foreign language, } \\
\text { a different grammar and different way of thinking involved in } \\
\text { order to speak a language well. It takes much effort and time to } \\
\text { get there. (HB\#9) } \\
\text { - harder, because they not only teach a language, but also develop } \\
\text { cultural knowledge, communicative competence, and another } \\
\text { way of seeing the world. (HA\#4) }\end{array}$ \\
\hline & $\begin{array}{l}\text { Theme } 2.2 \\
\text { (L1-centred } \\
\text { learning } \\
\text { context) } \\
\mathrm{TA}(\mathrm{n}=6) \\
\mathrm{HA}(\mathrm{n}=1) \\
\mathrm{HB}(\mathrm{n}=1)\end{array}$ & $\begin{array}{l}\text { - harder, especially in Turkey, because the language is not similar } \\
\text { to English. (TA\#3) } \\
\text { - harder, because they have to teach a language that is usually } \\
\text { very different from their and their students' mother tongue. } \\
\text { (HP\#10) } \\
\text { - harder because the second language is very hard to learn for } \\
\text { students. They need to be exposed to language. Very hard in } \\
\text { Turkey. Excessive use of L1. (TA\#5) }\end{array}$ \\
\hline & $\begin{array}{c}\text { Theme } 2.3 \\
\text { (fixed negative } \\
\begin{array}{c}\text { learner } \\
\text { attitudes) }\end{array} \\
\mathrm{TA}(\mathrm{n}=2) \\
\mathrm{HA}(\mathrm{n}=2) \\
\mathrm{HB}(\mathrm{n}=2)\end{array}$ & $\begin{array}{l}\text { - harder because students are not interested in learning } \\
\text { anymore. They do anything in the lesson except learning. } \\
\text { (HB\#7) } \\
\text { - harder, because it requires not just subject knowledge, but also } \\
\text { positive attitude to the language, and openness to new things. } \\
\text { (HA\#6) } \\
\text { - harder because the language itself should be used interactively. } \\
\text { It may be quite hard if students don't like the foreign language. } \\
\text { (TA\#16) }\end{array}$ \\
\hline & $\begin{array}{l}\text { Theme } 2.4 \\
\text { (methodolo- } \\
\text { gical } \\
\text { challenges) } \\
\mathrm{TA}(\mathrm{n}=1) \\
\mathrm{HB}(\mathrm{n}=2)\end{array}$ & $\begin{array}{l}\text { - harder because language (especially English) is very important } \\
\text { and could be taught in many ways. (HB\#1) } \\
\text { - harder because the trends in language teaching are incessantly } \\
\text { changing, and a good teacher adapts these and learns from } \\
\text { his/her previous mistakes. (HB\#3) }\end{array}$ \\
\hline
\end{tabular}




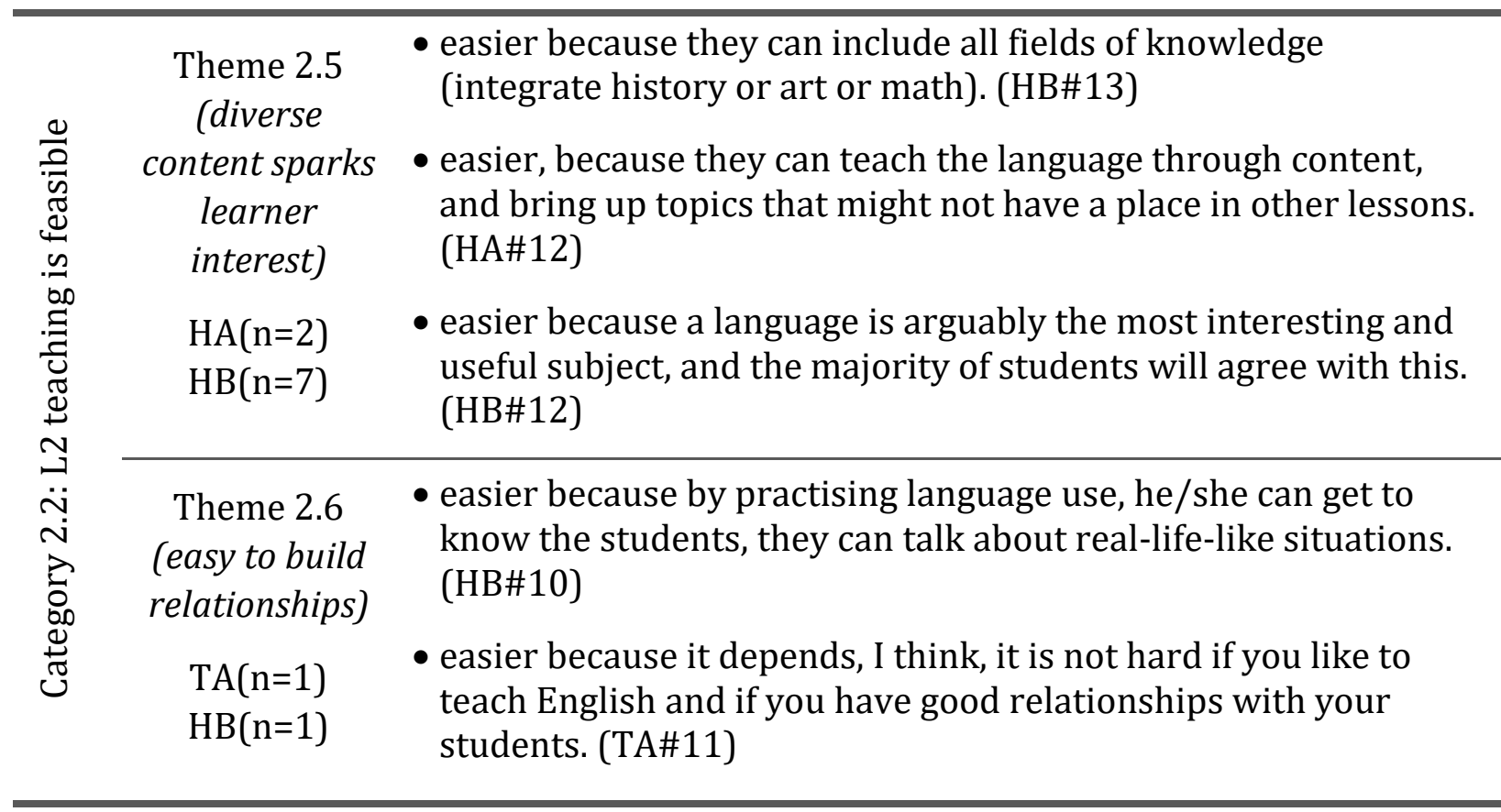

What is immediately apparent from Table 2 is that the majority of the participants positioned L2 teaching as more difficult than teaching other subjects, thereby drawing attention to the poorly researched tendency of pre-service EFL teachers to construct so called inhibitory beliefs (e.g., Peacock, 2001) and identities in which their professional growth and agency are limited by various external factors (e.g., Ruohotie-Lyhty, 2015). The category of such inhibitory beliefs (i.e. Category 2.1) incorporates images of hypothetical learners who are inactive in lessons because they "do not like the foreign language" (Theme 2.3), and fears that a teacher working in an L1-centred learning context (Theme 2.2) has little chance to change these fixed learner attitudes, especially if he or she is a non-native speaker of the L2 (Medgyes, 2015). Additionally, several participants constructed a view of L2 acquisition as an overly complex mental activity (Theme 2.1), demanding a methodological repertoire that pre-service EFL teachers can hardly live up to (Theme 2.4).

In view of these results, it is worth noting that discursive fragments such as the ones displayed in Category 2.1 are known to negatively affect pre-service EFL teachers' beliefs and classroom practices, often posing a long-term threat not only to student learning but also to teachers' sense of agency, autonomy, and self-efficacy (Moore, 2004; Peacock, 2001; Ruohotie-Lyhty, 2015). For this reason, if such categories of inhibitory beliefs and expectations are not exposed and mitigated in the pre-service years of language teacher education, they may also have long-term negative effects on teacher motivation, wellbeing, and job satisfaction (Dörnyei \& Kubanyiova, 2014; Lampert et al., 2012).

At the same time, the content of Category 2.2 is indicative of a completely different set of beliefs, equally viable but clearly more conducive to EFL teachers' motivation. More specifically, perspectives of L2 teaching as a mediation of diverse content (Theme 2.5) and a tool for building positive teacher-student relationships (Theme 2.6) can be seen as examples of conducive but realistic future self-guides (Dörnyei \& Kubanyiova, 2014), and it is an 
auspicious finding that eight members of Group HB held such beliefs and expectations. In contrast, the scarcity of such expectations in the other two groups seems to call, once again, for dialogic reflective activities in which existing beliefs can be externalised, communally discussed, and potentially reconceptualised (Chick, 2015; Kumaravadivelu, 2012). This is especially important in the case of pre-service EFL teachers, as their teaching-related beliefs and expectations are still highly adaptive to changes resulting from teaching practice, professional coursework, and the reflective activities in which they are engaged (Johnson, 2015; Yuan \& Lee, 2014).

\section{Conclusions}

In light of the qualitative results of this study, it is supposedly a well-founded conclusion that exploring and shaping teaching-related visions, expectations, and future self-guides are relevant tasks for the educators of pre-service EFL teachers (Dörnyei \& Kubanyiova, 2014). Although the belief-statements elicited from the Hungarian and Turkish participants are too short to capture the apparent complexity of language teachers' visions and future self-guides (see Kubanyiova, 2009), the study can be regarded as a source of new conceptual insights and implications for language teacher education. Most notably, the emerging themes in Section 4.2 have provided clear evidence of pre-service EFL teachers' tendency to hold beliefs that are inhibitory to teacher motivation and professional growth (Dörnyei \& Kubanyiova, 2014; Peacock, 2001), thereby drawing attention to reflective activity as a tool for exposing and possibly deconstructing beliefs and expectations of this type. In addition, the majority of beliefs in this category (i.e. Category 2.1 in Table 2) proved to be characteristic of all examined groups, signalling problematic questions and themes that should be better addressed through professional coursework with the participants involved, and possibly with pre-service EFL teachers in general (see Chick, 2015; Kumaravadivelu, 2012).

Regarding the question of visions and future self-guides, another crucial implication of the study is that the reflective activities of pre-service EFL teachers should not only serve to bring existing beliefs into focal awareness, but also to expose individuals to more attainable alternatives (e.g., Category 1.2 in Table 1) and thus enhance the adoption and construal of realistic and positively loaded future self-guides (Dörnyei \& Kubanyiova, 2014). In this sense, as Kalaja and Mäntylä (2018) point out, the aim of this specific type of reflective activity is

"to make student teachers aware of their beliefs about their professional future, and to reaffirm or reconsider these, which will possibly have consequences for the principles and practices that they will apply in their teaching once they enter working life as qualified teachers." (p. 35)

Having provided an illustration through results and an instrument for this type of reflective activity, I hope to encourage teacher educators to make reflection on visions and expectations a regular part of their professional coursework with pre-service EFL teachers, 
thus providing them with additional spaces for constructive discussion and professional growth.

\section{References}

Barkhuizen, G., \& Wette, R. (2008). Narrative frames for investigating the experiences of language teachers. System, 36(3), 372-387.

Bartlett, L. (1990). Teacher development through reflective teaching. In J. C. Richards \& D. Nunan (Eds.), Second language teacher education (pp. 202-214). Cambridge: Cambridge University Press.

Borg, S. (2003). Teacher cognition in language teaching: A review of research on what language teachers think, know, believe and do. Language Teaching, 36, 81-109.

Borg, S. (2006). Teacher cognition and language education: Research and practice. London: Continuum.

Borg, S., Birello, M., Civera, I., \& Zanatta, T. (2014). The impact of teacher education on preservice primary English language teachers. London: British Council.

Borg, S., \& Edmett, A. (2018). Developing a self-assessment tool for English language teachers. Language Teaching Research. doi: 10.1177/1362168817752543

Breen, M. P. (1999). Teaching language in the postmodern classroom. In R. Ribé (Ed.), Developing learner autonomy in foreign language learning (pp. 47-64). Barcelona: University of Barcelona Press.

Chick, M. (2015). The education of language teachers: Instruction or conversation? ELT Journal, 69(3), 297-307.

Clarke, M. (2008). Language teacher identities: Co-constructing discourse and community. Clevedon: Multilingual Matters.

Dombaycl, M. (2016). "New generation will be the mirror of them": An exploratory study of Turkish pre-service and novice EFL teachers' expectations and beliefs (Unpublished master's thesis). University of Pécs: Pécs.

Dörnyei, Z. (2009). The L2 motivational self system. In Z. Dörnyei \& E. Ushioda (Eds.), Motivation, language identity and the L2 self (pp. 9-42). Bristol: Multilingual Matters.

Dörnyei, Z., \& Chan, L. (2013). Motivation and vision: An analysis of future L2 self images, sensory styles, and imagery capacity across two target languages. Language Learning, 63(3), 437-462.

Dörnyei, Z., \& Kubanyiova, M. (2014). Motivating learners, motivating teachers: Building vision in the language classroom. Cambridge: Cambridge University Press.

Dörnyei, Z., \& Ryan, S. (2015). The psychology of the language learner revisited. New York: Routledge.

Farkas, K. (2019). Reflective templates in language teacher education: A pilot study on Hungarian and Turkish pre-service EFL teachers' beliefs. Argumentum, 15, 201-212.

Feryok, A. (2012). Activity theory and language teacher agency. The Modern Language Journal, 96(1), 95-107. 
Hyland, K., \& Wong, L. L. C. (Eds.) (2013). Innovation and change in English language education. New York: Routledge.

Johnson, K. E. (2009). Second language teacher education: A sociocultural perspective. New York: Routledge.

Johnson, K. E. (2015). Reclaiming the relevance of L2 teacher education. The Modern Language Journal, 99(3), 515-528.

Kalaja, P. (2015). 'Dreaming is believing': The teaching of foreign languages as envisioned by student teachers. In P. Kalaja, A. M. F. Barcelos, M. Aro, \& M. Ruohotie-Lyhty (Eds.), Beliefs, agency and identity in foreign language learning and teaching (pp. 124-146). New York: Palgrave Macmillan.

Kalaja, P., \& Mäntylä, K. (2018). 'The English class of my dreams': Envisioning teaching a foreign language. In S. Mercer \& A. Kostoulas (Eds.), Language teacher psychology (pp. 34-52). Bristol: Multilingual Matters.

Kelchtermans, G. (2009). Who I am in how I teach is the message: Self-understanding, vulnerability and reflection. Teachers and Teaching: Theory and Practice, 15, 257-272.

Kontra, M. (2016). Ups and downs in English language teacher education in Hungary in the last half century. Working Papers in Language Pedagogy, 10, 1-16.

Korthagen, F. A. J. (2004). In search of the essence of a good teacher: Towards a more holistic approach in teacher education. Teaching and Teacher Education, 20, 77-97.

Korthagen, F. A. J. (2011). Making teacher education relevant for practice: The pedagogy of realistic teacher education. Orbis Scholae, 5(2), 31-50.

Kubanyiova, M. (2009). Possible selves in language teacher development. In Z. Dörnyei \& E. Ushioda (Eds.), Motivation, language identity and the L2 self (pp. 314-332). Bristol: Multilingual Matters.

Kubanyiova, M., \& Feryok, A. (2015). Language teacher cognition in applied linguistics research: Revisiting the territory, redrawing the boundaries, reclaiming the relevance. The Modern Language Journal, 99(3), 435-449.

Kumaravadivelu, B. (2012). Language teacher education for a global society: A modular model for knowing, analyzing, recognizing, doing, and seeing. New York \& Oxon: Routledge.

Lampert, J., Burnett, B., \& Davie, S. (2012). Preparing high achieving English teachers to work in disadvantaged schools: 'I'll teach Shakespeare when I'm 60'. English in Australia, 47(3), 69-77.

Lugossy, R. (2006). Shaping teachers' beliefs through narratives. In M. Nikolov \& J. Horváth (Eds.), UPRT 2006: Empirical studies in English applied linguistics (pp. 329-352). Pécs: Lingua Franca Csoport.

McDiarmid, G. W., \& Clevenger-Bright, M. (2008). Rethinking teacher capacity. In M. CochranSmith, S. Feiman-Nemser, D. J. McIntyre, \& K. E. Demers (Eds.), Handbook of research on teacher education: Enduring questions in changing contexts (3rd ed.) (pp. 134-156). New York \& Oxon: Routledge.

Medgyes, P. (2015). Töprengések a nyelvtanításról. Budapest: Eötvös Kiadó.

Peacock, M. (2001). Pre-service ESL teachers' beliefs about second language learning: A longitudinal study. System, 29(2), 177-195. 
Moore, A. (2004). The good teacher: Dominant discourses in teaching and teacher education. London \& New York: RoutledgeFalmer.

Ruohotie-Lyhty, M. (2015). Dependent or independent: The construction of the beliefs of newly qualified foreign language teachers. In P. Kalaja, A. M. F. Barcelos, M. Aro, \& M. Ruohotie-Lyhty (Eds.), Beliefs, agency and identity in foreign language learning and teaching (pp. 149-171). New York: Palgrave Macmillan.

Toköz Göktepe, F. (2015). A critical analysis of foreign language teacher education practices in Turkey. International Journal of Languages' Education and Teaching, 3(1), 128-143.

Warren, C. A. (2018). Empathy, teacher dispositions, and preparation for culturally responsive pedagogy. Journal of Teacher Education, 69(2), 169-183.

Yuan, R., \& Lee, I. (2014). Pre-service teachers' changing beliefs in the teaching practicum: Three cases in an EFL context. System, 44, 1-12.

\section{Appendix A: The reflective template serving as data collection instrument for the study}

Complete the sentences below to form statements about your views as a teacher. In sentences that offer you a choice between two options (marked with a slash), please, underline the one that you will argue for. There are no right and wrong answers, the point is that the statements hold true for you.

1. If I think of a good language teacher, the first thing that comes to my mind is...

2. If I was working as a teacher, the most important thing I would teach my students is...

3. One thing I would never do as a teacher is...

4. If there's one thing that annoys a teacher, it is...

5. If I could give a piece of advice to my old language teacher, it would be to...

6. Besides the subject knowledge, a language teacher needs to know...

7. The job of a language teacher is harder / easier, because...

8. A teacher's personality is also important / not so important, because...

9. I once had a language teacher who...

10. The ideal teacher is... 